\title{
Unilateral Palmar Post-traumatic Granuloma Annulare - Work-related?
}

\author{
Anca Chiriac ${ }^{1,2,3}$, Piotr Brzezinski ${ }^{4}$, Liliana Foia 5 , Horațiu Moldovan ${ }^{6}$, Cristian Podoleanu , Adrian \\ Năznean ${ }^{8}$ Simona Stolnicu ${ }^{9}$ \\ ${ }^{1}$ Apollonia University, Department of Dermatology, lași, Romania \\ 2 "P. Poni” Institute of Macromolecular Chemistry, Iași, Romania \\ ${ }^{3}$ Nicolina Medical Center, Iași, Romania \\ 4 6th Military Support Unit, Utska, Poland \\ 5 “Grigore T. Popa” University of Medicine and Pharmacy, Iași, Romania \\ 6 Department of Occupational Medicine, University of Medicine, Pharmacy, Science and Technology, Târgu Mureș, Romania \\ 7 Department of Cardiology, University of Medicine, Pharmacy, Science and Technology, Târgu Mureș, Romania \\ 8 Department of Foreign Languages, University of Medicine, Pharmacy, Science and Technology, Târgu Mureș, Romania \\ 9 Department of Pathology, University of Medicine, Pharmacy, Science and Technology, Târgu Mureș, Romania
}

\section{CORRESPONDENCE}

\section{Adrian Năznean}

Str. Gheorghe Marinescu nr. 38

540139 Târgu Mureș, Romania

Tel: +40 265215551

E-mail: adinaznean@yahoo.com

\section{ARTICLE HISTORY}

Received: January 16, 2019

Accepted: April 17, 2019
Anca Chiriac • Str. Hatman Șendrea nr. 2, 700613 lași, Romania. Tel: +40 332808703

Piotr Brzezinski • Department of Dermatology, 6th Military Support Unit, os. Ledowo 1N, 76-270 Ustka, Poland. Tel: +48 692121516

Liliana Foia • Str. Universitătii nr. 16, 700115 lași, Romania. Tel: +40 232301600

Horatiu Moldovan • Str. Gheorghe Marinescu nr 38 540139 Târgu Mureș, Romania. Tel: +40 265215551 Cristian Podoleanu • Str. Gheorghe Marinescu nr. 38 540139 Târgu Mureș, Romania. Tel: +40 265215551

Simona Stolnicu • Str. Gheorghe Marinescu nr. 38 540139 Târgu Mures, Romania. Tel: +40 26521555

\begin{abstract}
Granuloma annulare (GA) is a granulomatous skin condition that can present with a diversity of clinical manifestations and locations, with an unknown etiology and diagnosed on clinicalpathological grounds/correlations. Although many trigger factors have been described and several pathogenic mechanisms proposed, the etiology of GA remains unknown. We report a case of work-related, isolated, unilateral GA localized on the right palmar area of a young worker, possibly induced by work-related direct trauma.
\end{abstract}

Keywords: granuloma, annulare, palmar, work, occupational, dermatology

\section{INTRODUCTION}

Granuloma annulare (GA) is a granulomatous skin condition that can present with a diversity of clinical manifestations and locations, with an unknown etiology and diagnosed on clinical-pathological grounds/correlations. Although many trigger factors have been described and several pathogenic mechanisms proposed, the etiology of GA remains unknown.

We report a case of work-related, isolated, unilateral GA localized on the right palmar area of a young worker, possibly induced by work-related direct trauma.

The patient consented to publication of his data, and all examinations were performed in accordance to the principles stated in the Declaration of Helsinki. 


\section{CASE REPORT}

A 37-year-old man presented with a one-week history of annular erythematous lesions on the right palm, distributed mostly on the compression sites. He was a construction worker, handling a hydraulic hand breaker, used for breaking up concrete. The patient described his full-time job as working on average 10 hours daily with a portable jackhammer. He was a strong young, healthy person of $1.82 \mathrm{~m}$ height, who had to support the weight of the tool and the vibration induced by the machine and to handle the machine to break up stones, pavements, or concrete. He started this new job a few months before admission to the hospital; his previous jobs had not been in construction and had not been related to physical activity. Before starting work in construction, a careful medical examination was performed, data recorded, and he was declared a healthy person. Skin lesions on the right palm were observed by the patient and confirmed by his general practitioner a few days before admission to the hospital (Figure 1A).

Dermatological examination revealed several scattered round, well-demarcated, erythematous papules with annulare-type distribution, with an inflammatory rim, localized on the right palm and ventral area of digits II, III, and IV. No scratching marks, due to the absence of pruritus, and no other skin lesions on the body could be observed. The patient was otherwise in good health, no drug intake was noted, and no allergy history was reported.

A punch-biopsy was taken from one of the lesions, revealing a moderate superficial mid-dermal perivascular and interstitial infiltrate of lymphocytes and histiocytes, with mucin deposition between the collagen fibers (Figure 1B).
Based on the clinical and histological findings, a diagnosis of localized GA was established. Provocation test with pressure was not done due to time-work correlation and good evolution in the absence of physical vibration or other type of physical trauma on his palms. On admission to the hospital, he was routinely checked, and no systemic diseases were found. Apart from the chronic traumatic trigger factor, no other cause was detected for localized GA on the right palm.

After having been diagnosed with palmar GA, he was advised to change his work duties; he was treated with topical steroids and avoided any type of physical work involving his right hand, working in administration, as a storekeeper. Skin lesions improved gradually. He was transferred to a similar position within the same company in another city. Close follow-up of the cutaneous disease did not show any relapse in the absence of physical effort as it was recorded in his medical documents.

\section{DISCUSSIONS}

Granuloma annulare is a benign common disorder, with a variety of clinical aspects and an obscure etiology, several classifications being issued: localized, generalized (generalized annular GA, disseminated papular GA, atypical generalized GA), subcutaneous, and perforating GA.

Localized GA is a benign inflammatory disease of unknown etiology, mostly described in children. The first description of the disease dates from 1895, when Colcott-Fox reported the case of a 11-year-old female child with "ring eruption on the fingers". ${ }^{1}$ The name granuloma annulare was given to the cutaneous disease by Radcliff-Crocker in 1902 as a descriptive terminology highlighting the an-
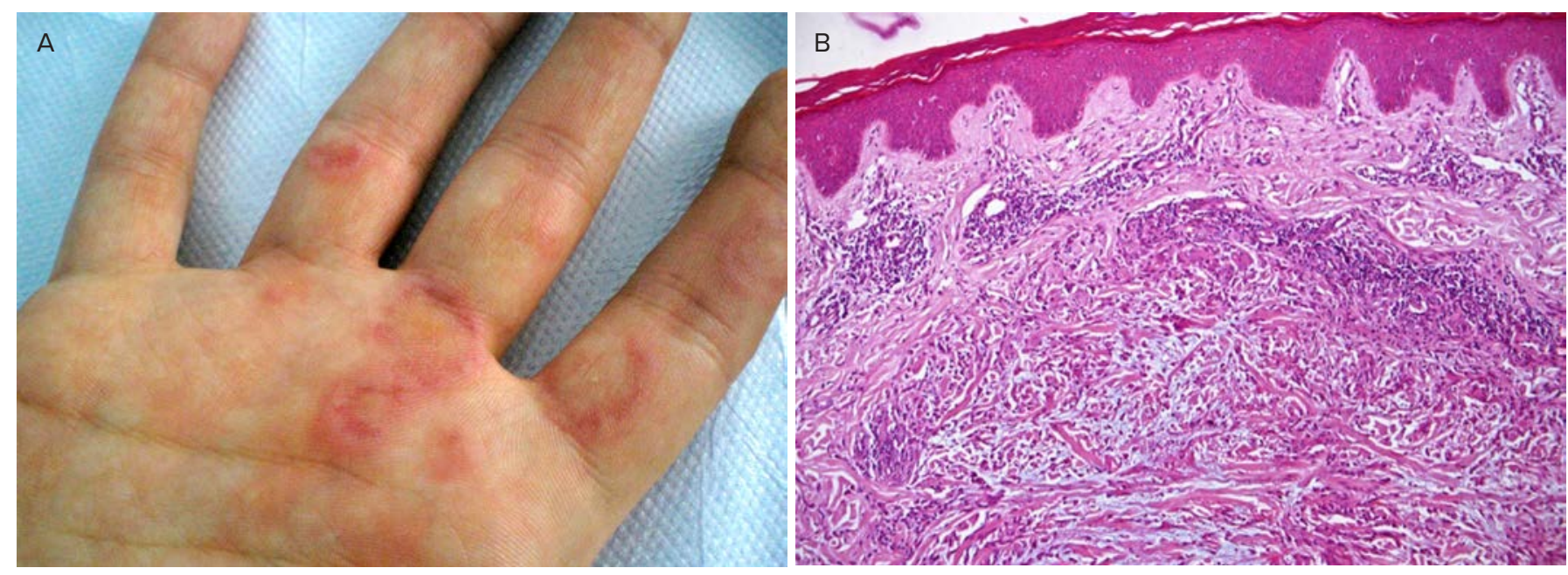

FIGURE 1. A - Annular erythematous plaques on the right palmar area; B - Histological appearance: moderate superficial and middermal interstitial and perivascular infiltrate, predominantly composed of lymphocytes and histiocytes, and mucin deposition between the collagen bundles/fibers. Hematoxylin and eosin, $\times 40$. 
nular (ring-type) distribution of the skin lesions and the granulomatous reaction localized in the dermis and subcutaneous tissue. ${ }^{2}$ Localized GA is frequently described in patients not older than 30 years, with papules distributed in annular fashion, free of symptoms or associated with pruritus, burning sensation, localized mostly on the dorsal aspect of the hands, on the elbows, or inferior limbs; GA on the palms is rarely described.

Although the underlying pathogenic mechanisms remain unclear, different theories have been proposed, based on delayed-type hypersensitivity reaction, ${ }^{3}$ Th1 involvement, ${ }^{4}$ lymphocyte-mediated activation of monocytes, ${ }^{5}$ and elastic tissue injury. ${ }^{6}$

Localized forms of GA on the dorsa of the hands have been frequently reported, but the same lesions on the palms are rare. ${ }^{7}$ In both situations, localized factors have been correlated with localized GA: ultraviolet light or trauma, ${ }^{8}$ arthropod bites, ${ }^{9}$ tuberculin skin tests, ${ }^{10}$ viral infections, ${ }^{11}$ and psoralen plus ultraviolet A photochemotherapy (PUVA). ${ }^{12}$ Of interest, GA on the palm has been reported to be associated with systemic disorders such as rheumatic diseases and malignancies. ${ }^{13,14} \mathrm{~A}$ report of GA induced by trauma was published in 1992, when two cases involving the external ears of males were presented. ${ }^{15}$ More recently, a case of papular GA of the dorsal aspects of the hands induced by repeated, direct trauma to the site was published, rising therefore the idea of a possible role of direct trauma in the pathogenesis of GA. ${ }^{8}$

\section{CONCLUSIONS}

The particularity of the present case is represented by unilateral right palmar type of granuloma annulare in a 37-year-old healthy man, possibly induced by a traumatic trigger factor (vibration and pressure exerted by a hydraulic hand breaker).

\section{CONFLICT OF INTEREST}

Nothing to declare.

\section{REFERENCES}

1. Colcott-Fox T. Ringed eruptions of the fingers. Br J Dermatol. 1895;7:91-95. 2. Radcliff-Crocker H. Granuloma annulare. Br J Dermatol. 1902;14:1-9.

3. Buechner SA, Winkelmann RK, Banks PM. Identification of T-cell subpopulations in granuloma annulare. Arch Dermatol. 1983;119:125-128.

4. Fayyazi A, Schweyer S, Eichmeyer B, et al. Expression of IFN-gamma, coexpression of TNF-alpha and matrix metalloproteinases and apoptosis of T Iymphocytes and macrophages in granuloma annulare. Arch Dermatol Res. 2000;292:384-390.

5. Umbert P, Winkelmann RK. Histologic, ultrastructural and histochemical studies of granuloma annulare. Arch Dermatol. 1977;113:1681-86.

6. Hanna WM, Moreno-Merlo F, Andrighetti L. Granuloma annulare: an elastic tissue disease? Case report and literature review. Ultrastruct Pathol. 1999;23:33-38.

7. Stewart LR, George S, Hamacher KL, Hsu S. Granuloma annulare of the palms. Dermatol Online J. 2011;17:7.

8. Hu SW, Kaplan J, Patel RR, Kamino H. Trauma-related papular granuloma annulare. Dermatol Online J. 2013;19:207-219.

9. Moyer DG. Papular granuloma annulare. Arch Dermatol. 1964;89:41-45.

10. Houcke-Bruge C, Delaporte E, Catteau B, Martin De Lassalle E, Piette F. Granuloma annulare following BCG vaccination. Ann Dermato/ Venereol. 2001;128:541-554

11. Ezra N, Ahdout J, Haley JC, Chiu MW. Granuloma annulare in a zoster scar of a patient with multiple myeloma. Cutis. 2011;87:240-244.

12. Jang EJ, Lee JY, Kim MK, Yoon TY. Erythematous granuloma annulare. Ann Dermatol. 2011;23:409-411.

13. Takeyama J, Sanada T, Watanabe M, Hatori M, Kunikata N, Aiba S. Subcutaneous granuloma annulare in a child's palm: a case report. J Hand Surg Am. 2006;31:103-106.

14. Barksdale S., Perniciaro C, Halling KC, Strickler JG. Granuloma annulare in patients with malignant lymphoma: clinicopathologic study of thirteen new cases. J Am Acad Dermatol. 1994;31:42-48.

15. Mills A, Chetty R. Auricular granuloma annulare. A consequence of trauma? Am J Dermatopathol. 1992;14:431-433. 